\title{
Air quality improvement during triple-lockdown in the coastal city of Kannur, Kerala to combat Covid-19 transmission
}

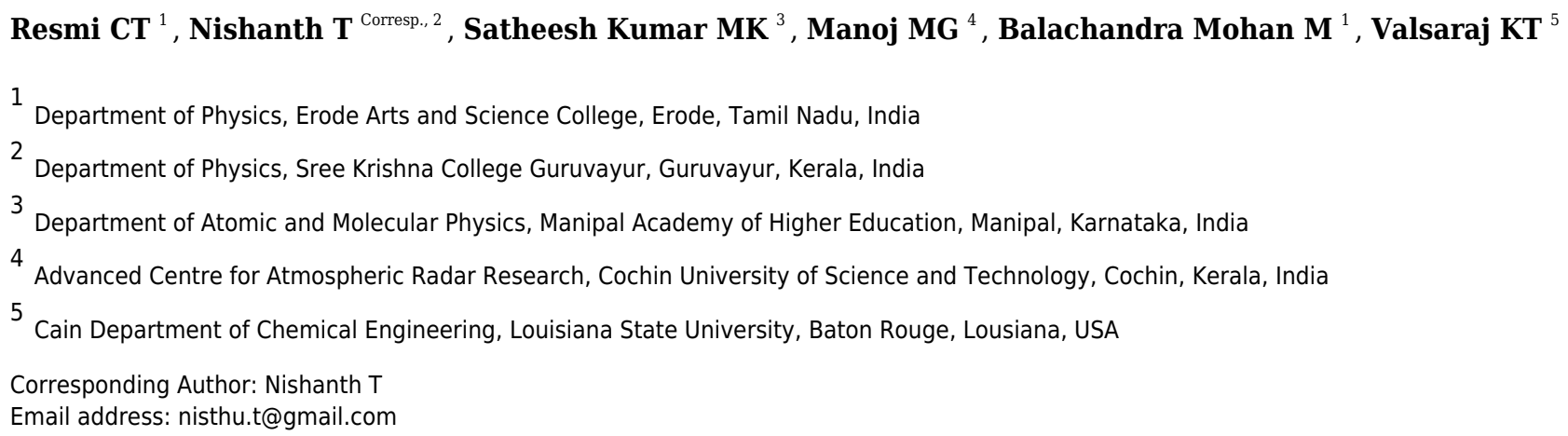

The novel SARS-CoV-2 coronavirus that emerged in the city of Wuhan, China, last year has since become the COVID-19 pandemic across all continents. To restrict the spread of the viruspandemic, the Government of India imposed a lockdown on 25 March 2020. In India, Kannur district was identified as the first "hotspot" of virus transmission and a "triplelockdown" was implemented for a span of twenty days from 20 April 2020. This paper highlights the variations of surface $\mathrm{O}_{3}, \mathrm{NO}, \mathrm{NO}_{2}, \mathrm{CO}, \mathrm{SO}_{2}, \mathrm{NH}_{3}, \mathrm{VOC}^{\prime} \mathrm{s}, \mathrm{PM}_{10}, \mathrm{PM}_{2.5}$ and meteorological parameters at the time of pre-lockdown, lockdown and triple-lockdown days at Kannur town in south India using ground-based analyzers. From pre-lockdown days to triple-lockdown days, surface $\mathrm{O}_{3}$ concentration was found to increase by $22 \%$ in this VOC limited environment. $\mathrm{NO}$ and $\mathrm{NO}_{2}$ concentrations were decreased by $61 \%$ and $71 \%$ respectively. The concentration of $\mathrm{PM}_{10}$ and $\mathrm{PM}_{2.5}$ were observed to decline significantly by $61 \%$ and $53 \%$ respectively. Reduction in $\mathrm{PM}_{10}$ during lockdown and triple-lockdown days enhanced the intensity of solar radiation reaching the lower troposphere, and increased air temperature and reduced the relative humidity. Owing to this, surface $\mathrm{O}_{3}$ production over Kannur was found to have increased during triple-lockdown days. The concentration of CO (67\%), VOCs (61\%), $\mathrm{SO}_{2}(62 \%)$, and $\mathrm{NH}_{3}(16 \%)$ were found to decrease significantly from pre-lockdown days to triple-lockdown days. The air quality index (AQI) revealed that the air quality at the observational site was clean during the lockdown. 
$1 \quad$ Air quality improvement during triple-lockdown in the coastal city of

4 Resmi CT ${ }^{1}$, Nishanth $T^{* 2}$, Satheesh Kumar MK $^{3}$, Manoj MG ${ }^{4}$, Balachandramohan $\mathbf{M}^{1}$, $5 \quad$ Valsaraj KT $^{5}$

$6{ }^{1}$ Department of Physics, Erode Arts and Science College, Tamil Nadu, India-638009

7 2Department of Physics, Sree Krishna College Guruvayur, Kerala, India- 680102

$8{ }^{3}$ Department of Atomic and Molecular Physics, Manipal Academy of Higher Education, 9 Karnataka, India- 576104

${ }^{4}$ Advanced Centre for Atmospheric Radar Research, Cochin University of Science \& 11 Technology, Kerala, India-682022

${ }^{4}$ Cain Department of Chemical Engineering, Louisiana State University, USA-70803

*Corresponding author: Nishanth $\mathbf{T}$

Department of Physics, Sree Krishna College Guruvayur, Kerala India- 680102

Corresponding_author_email: nisthu.t@gmail.com 
Abstract:

The novel SARS-CoV-2 coronavirus that emerged in the city of Wuhan, China, last year has since become the COVID-19 pandemic across all continents. To restrict the spread of the virus pandemic, the Government of India imposed a lockdown on 25 March 2020. In India, Kannur district was identified as the first "hotspot" of virus transmission and a "triple-lockdown" was implemented for a span of twenty days from 20 April 2020. This paper highlights the variations of surface $\mathrm{O}_{3}, \mathrm{NO}, \mathrm{NO}_{2}, \mathrm{CO}, \mathrm{SO}_{2}, \mathrm{NH}_{3}, \mathrm{VOC}$ 's, $\mathrm{PM}_{10}, \mathrm{PM}_{2.5}$ and meteorological parameters at the time of pre-lockdown, lockdown and triple-lockdown days at Kannur town in south India using ground-based analyzers. From pre-lockdown days to triple-lockdown days, surface $\mathrm{O}_{3}$ concentration was found to increase by $22 \%$ in this VOC limited environment. NO and $\mathrm{NO}_{2}$ concentrations were decreased by $61 \%$ and $71 \%$ respectively. The concentration of $\mathrm{PM}_{10}$ and $\mathrm{PM}_{2.5}$ were observed to decline significantly by $61 \%$ and $53 \%$ respectively. Reduction in $\mathrm{PM}_{10}$ during lockdown and triple-lockdown days enhanced the intensity of solar radiation reaching the lower troposphere, and increased air temperature and reduced the relative humidity. Owing to this, surface $\mathrm{O}_{3}$ production over Kannur was found to have increased during triplelockdown days. The concentration of $\mathrm{CO}(67 \%)$, VOCs $(61 \%), \mathrm{SO}_{2}(62 \%)$, and $\mathrm{NH}_{3}(16 \%)$ were found to decrease significantly from pre-lockdown days to triple-lockdown days. The air quality index (AQI) revealed that the air quality at the observational site was clean during the lockdown.

Keywords: COVID-19, Lockdown, Kannur, Air pollutants, Air quality 
92 2015). These hydrocarbons play a crucial role in the photochemical production of $\mathrm{O}_{3}$ and other 93 oxidants in the lower atmosphere (Atkinson 2000; Srivastava et al. 2005).

94

$\mathrm{SO}_{2}$ is released into the atmosphere through both natural and anthropogenic emissions. Natural sources are mainly by volcanic eruptions while anthropogenic sources include the combustion of all sulfur containing fuels like oil coal and diesel used for the power generation for industrial activities (Mallik and Lal 2014; Zhang et al. 2017). Industrial and traffic emissions are the major ammonia $\left(\mathrm{NH}_{3}\right)$ sources in an urban environment (Pandolfi et al. 2012; Phan et al. 2013).

Severe Acute Respiratory Syndrome Corona Virus-2 (SARS-CoV2) is the pathogenic agent of Covid-19, a disease first reported from Wuhan Hubei Province of China in December 2019. It was declared a global pandemic by the World Health Organization (WHO) on 11 March 2020 (Al-Qahtani 2020). The course of the disease is often mild undistinguishable from severed pneumonia which eventually led to acute respiratory distress syndrome (ARDS) and death (Lu et al. 2020). India reported the first confirmed case of coronavirus infection on 30 January 2020 in the southern state of Kerala (Gautam and Hens 2020). To stop the spread of the virus pandemic, many countries have decided to enforce lockdown measures even as they northern part of Kerala state on the global economy. Subsequently, the Government of India imposed a countrywide lockdown to implement the Break-the-Chain mission to curtail its spread for 21 days in its first phase, and extended up to a second spell of 19 days and a final third phase of 14 days up to May 17 for a total of 54 days. As a result, tightened restrictive measures (i.e. closure all academic institutes, industries, markets, malls and all public places, non-essential businesses, limitation of motorized transports, shut down of Indian railway network, cancellation of inbound and outbound flights) were implemented throughout the nation to impose social distancing.

A substantial enhancement in the air quality in the lockdown period from all over the world were reported. Air pollution in China was significantly reduced as more people quarantined to prevent the social spread of Covid-19 (Dutheil et al. 2020; Muhammad et al. 2020; Wang and Su 2020). Bao and Zhang (2020) reported that the concentrations of $\mathrm{SO}_{2}$, $\mathrm{PM}_{2.5}, \mathrm{PM}_{10}, \mathrm{NO}_{2}$, and $\mathrm{CO}$ over 44 cities in northern China have decreased significantly by $6.76 \%, 5.93 \%, 13.66 \%, 24.67 \%$, and $4.58 \%$, respectively due to vehicular restrictions during lockdown period. In addition to these, they conclude that these reduction in air pollutants caused a decrease in air quality index by $7.80 \%$ over these cities in China. 
123 Likewise, Community Multi-scale Air Quality Model (CMAQ) analysis carried out by Wang et 124 al. (2020) found that, $\mathrm{PM}_{2.5}$ concentration over different parts of urban areas in China were 125 significantly reduced in lockdown period. The findings of Shi and Brasseur (2020) showed that 126 particulate matter pollution decreased by an average of 35 percent and nitrogen dioxide 127 decreased by an average of 60 percent in northern China after the lockdowns began on January 128 23. However, the study found the average surface $\mathrm{O}_{3}$ concentration increased by a factor of 1.5-2 129 over the same time period. Bauwens et al. (2020) also observed a substantial decrease of $\mathrm{NO}_{2}$ 130 column by $40 \%$ over cities in China and 20-38\% in Western Europe and USA.

Kanniah et al. (2020) reported that $\mathrm{PM}_{10}, \mathrm{PM}_{2.5}, \mathrm{NO}_{2}, \mathrm{SO}_{2}$, and $\mathrm{CO}$ concentrations were

132

133

134

135

136

137

138

139

140

141

142

143

144

145

146

147

148

149

150

151

152 reduced to $26-31 \%, 23-32 \%, 63-64 \%, 9-20 \%$, and $25-31 \%$, respectively in urban regions of Malaysia during the lockdown period. Further, they revealed that the restricted industrial activities imposed in lockdown period resulted a reduced concentrations of Aerosol Optical Depth (AOD) and tropospheric $\mathrm{NO}_{2}$ over East Asian region. There were reports that air pollution was significantly reduced in Barcelona in Spain (Tobías et al. 2020) and European region (Sicard et al. 2020) due to the lockdown to prevent Covid-19 spread. A decline in $\mathrm{NO}_{2}$, $\mathrm{NO}$ and an increase in surface $\mathrm{O}_{3}$ was observed at Sao Paulo in Brazil during lockdown period (Dantas et al. 2020; Nakada et al. 2020). Air pollution levels have dropped significantly in India due to a massive dip in vehicular movement and industrial activity which have resulted in clean and fresh air (Gautam 2020; Mahato et al. 2020; Sharma et al. 2020).

In the meantime, Kerala state government imposed a "triple-lockdown" in Kannur from 20 April for 20 days after identifying Kannur as a "hotspot" of Covid-19 and declared it a "red" zone in the state. The "triple-lockdown" involved a combination of technology and human surveillance and movement restrictions ple by providing one entry and exit point in all abodes leaving all other roads closed for traffic. People in red zones were not allowed to leave their houses and essential items were made available through local authorities through specific requests. Further, guards were deployed to ensure that people in the containment zones stayed indoors during the entire period of the lockdown. During the general lockdown and triplelockdown periods, the skies over the polluted cities quickly cleared and smelled of fresh air. This offered a rare occasion for investigating how the air pollution levels responded to an extraordinary development. 
In this work, we describe the trend in air pollution via monitoring the variations of 154 surface ozone $\left(\mathrm{O}_{3}\right)$, oxides of nitrogen $\left(\mathrm{NO}\right.$ and $\left.\mathrm{NO}_{2}\right)$, particulate matters $\left(\mathrm{PM}_{10}\right.$ and $\left.\mathrm{PM}_{2.5}\right)$, 155 carbon monoxide (CO), volatile organic compounds (VOC's) including benzene, toluene, ethyl 156 benzene, xylene, o-xylene (collectively called BTEX), sulphur dioxide $\left(\mathrm{SO}_{2}\right)$, ammonia $\left(\mathrm{NH}_{3}\right)$, 157 and meteorological parameters at the time of pre-lockdown, lockdown and triple-lockdown days 158 at Kannur town in the Kerala state of South India.

\section{Methodology}

\subsection{Observational site}

Kannur was the British military headquarters on the west coast of India until 1987.

162

163

164

165

166

167

168

169

170

171

172

173

174

175

176

177

178

179

180

181

182

183

Kannur has had its industrial importance from very early days. It was an important trading center of the $12^{\text {th }}$ century with an active business relationship with European and Arab countries. When the state of Kerala was formed in 1957, it was named Kannur town, because administrative offices were established in the district. Kannur is the sixth-most urbanized district in Kerala, with more than $50 \%$ of its residents living in urban areas. The district is known for its high level of literacy and health care. Kannur experiences a summer season from March to the end of May. This is followed by the south-west monsoon until September. Even the smallest pollution in the atmosphere of Kannur affects the quality of the air and subsequently the health of the people here. In the first phase of Covid-19, Kannur district reported the highest number of cases in Kerala till 15 May. Ground based observations were carried out at Kannur town to investigate the variations of different trace pollutants in the atmosphere from pre-lockdown days to triplelockdown days. The observational site lies in a coastal belt along the Arabian Sea and is very close to the National Highway (NH 17). Observational site at Kannur town $\left(11.87^{\circ} \mathrm{N} 75.37^{\circ} \mathrm{E}\right.$ $3 \mathrm{~m} \mathrm{msl}$ ) in northern part of Kerala state. Kannur in south India is shown in the figure 1(a) and the aerial view of Kannur town and surroundings with observational site is shown in the figure $1(b)$.

\subsection{Experimental setup}

Observations of trace pollutants were carried out using the respective ground based gas analyzers from Environment S.A France. The measurements of the $\mathrm{O}_{3}$ were made using a continuous $\mathrm{O}_{3}$ analyzer (Model O342e) with a detection limit of 0.2.ppbv. Its working principle is based on $\mathrm{O}_{3}$ detection by direct absorption in UV light. $\mathrm{O}_{3}$ absorption spectrum is intense in the 250 and $270 \mathrm{~nm}$ wavelength range. Thus, it corresponds to the maximum range of $\mathrm{O}_{3}$ 
184 absorption at $255 \mathrm{~nm}$. $\mathrm{NO}, \mathrm{NO}_{2}$ and $\mathrm{NH}_{3}$ were measured with the aid of gas analyzer (Model 185 AC32e) with a detection limit of $0.2 \mathrm{ppbv}$. Its working principle is based on the NO 186 chemiluminescence in the presence of highly oxidizing $\mathrm{O}_{3}$ molecules. The NO in the ambient air 187 is oxidized by $\mathrm{O}_{3}$ to form excited $\mathrm{NO}_{2}$ molecules. The concentrations of $\mathrm{NO}, \mathrm{NO}_{2}$ were 188 measured based on the spectrum of the radiation emitted by $\mathrm{NO}_{2}$ molecules at the excited level. 189 Particulate matters $\left(\mathrm{PM}_{10}\right.$ and $\left.\mathrm{PM}_{2.5}\right)$ were measured by using suspended particulate beta gauge 190 monitor (Model MP101M). Its working principle is based on the particle measurement by beta 191 radiation attenuation. The measurement consists of calculating the absorption difference between 192 a blank filter and a loaded filter, knowing that the beta ray absorption follows an exponential law 193 and is independent of the physiochemical nature of the particles.

194 Measurements of CO were made by using an analyzer (Model CO12e) with a detection 195 limit of $0.05 \mathrm{ppm}$. Its working principle is based on CO detection by absorption in infrared light. 196 VOC's (BTEX) were measured, based on gas chromatography coupled with a PID 197 detector by using (VOC72e) analyzer. $\mathrm{SO}_{2}$ measurements were made by using a UV fluorescent 198 sulfur dioxide analyzer (Model AF22e) with a detection limit of 0.4ppbv. The ambient air to be 199 analysed is filtered by a hydrocarbon removing aromatic molecule device. The hydrocarbon 200 molecule free sample to be analysed is sent to a reaction chamber, to be irradiated by an UV 201 radiation centred at $214 \mathrm{~nm}$, which is the $\mathrm{SO}_{2}$ molecule absorption wavelength. All the gas 202 analyzers have been calibrated by using sample gases on a regular basis. The total solar radiation 203 was measured by LSI LASTEM Italia (DPA870) pyranometer and surface air temperature 204 measured by an external Pt100 sensor.

\subsection{Air quality index calculation}

The Air Quality Index (AQI) is a scale designed to help us to understand the quality of the air we breathe and it also helps provide advice on how to improve air quality. Further, this index provides special awareness to the public who are sensitive to air pollution (Beig et al. 2010). Normally air pollution levels may be higher in towns, near power plants and large stationary emission sources. To identify the overall improvement in air quality over Kannur, air quality index (AQI) was calculated and the details of AQI are available elsewhere (CPCB, 2014; Sharma et.al 2020). The AQI is divided into five categories: good (0-50), satisfactory (51-100), moderate (101-200), poor (201-300), very poor (301-400) and severe (401-500) respectively.

214 The observed concentrations of $\mathrm{PM}_{10}, \mathrm{PM}_{2.5}, \mathrm{NO}_{2}, \mathrm{SO}_{2}, \mathrm{O}_{3}, \mathrm{CO}$ and $\mathrm{NH}_{3}$ were converted into air 
215 quality index using standard value. The air quality index (AQI) for each pollutant was calculated

216 by the following formula given by Sahu and Kota 2017.

217

$$
\text { AQIi }=\frac{\mathrm{I}_{\mathrm{HI}}-\mathrm{I}_{\mathrm{LO}}}{\text { Break }_{\mathrm{HI}}-\text { Break }_{\mathrm{LO}}} \mathrm{x}\left(\mathrm{C}_{\mathrm{i}}-\text { Break }_{\mathrm{LO}}\right)+\mathrm{I}_{\mathrm{LO}}
$$

218 Where $\mathrm{C}_{\mathrm{i}}$ is the observed concentration of the pollutant ' $\mathrm{i}$ '; Break $\mathrm{K}_{\mathrm{HI}}$ and Break $_{\mathrm{LO}}$ are breakpoint

219

220

221

222

223

224

225

226

227

228

229

230

231

232

233

234

235

236

237

238

239

240

241

242

243

concentrations greater and smaller to $\mathrm{C}_{\mathrm{i}}$; and $\mathrm{I}_{\mathrm{HI}}$ and $\mathrm{I}_{\mathrm{LO}}$ are corresponding air quality index ranges. Breakpoint concentration of different pollutants are provided by CPCB, (2014) and is shown in table 1.

\section{Results and Discussion}

\subsection{Variation of surface $\mathrm{O}_{3}, \mathrm{NO}, \mathrm{NO}_{2}$}

In order to study the impact of lockdown on the variation of trace pollutants over Kannur, the study period was divided into three spans; namely pre-lockdown period of 32 days (1-24 March 2020 and 10-17 May 2020), lockdown period of 25 days (25 March-19 April 2020), and a triple-lockdown period of 20 days (20 April to 9 May 2020). $\mathrm{O}_{3}$ concentration at Kannur town was very low (8-20ppbv) at night time and high (15-55ppbv) during the day time.

Figure 2(a) depicted a diurnal variation of $\mathrm{O}_{3}$ in Kannur town, and it shows that $\mathrm{O}_{3}$ was observed to be high during afternoon hours due to the photolysis $\mathrm{NO}_{2}$ in the presence of VOC's, $\mathrm{CO}$ and $\mathrm{CH}_{4}$. The observed low concentration at night-time was mainly due to the loss of $\mathrm{O}_{3}$ by the titration with NO (Nishanth et al. 2014). Diurnal variation of $\mathrm{O}_{3}$ showed a similar pattern in pre-lockdown days, lockdown days, and triple-lockdown days but with differences in their concentrations. The maximum concentration of $\mathrm{O}_{3}$ observed on pre-lockdown days lockdown days and triple-lockdown days were $(45.64 \pm 4.74 \mathrm{ppbv})(49.58 \pm 3.1 \mathrm{ppbv})$, and $(55.66 \pm 2.61 \mathrm{ppbv})$ respectively. Thus, an enhancement in $\mathrm{O}_{3}$ concentration was observed over Kannur from prelockdown days to triple-lockdown and this increase is $22 \%$.

The diurnal variations of $\mathrm{NO}$ and $\mathrm{NO}_{2}$ are shown in the figure 2(b) and 2(c) respectively. NO concentration was observed high in night and early morning hours and found to be low during afternoon hours. The diurnal average concentrations of NO observed during prelockdown, lockdown and triple-lockdown days were (5.4 $\pm 1.2 \mathrm{ppbv}),(3.5 \pm 1.1 \mathrm{ppbv})$, and $(2.1 \pm 0.82 \mathrm{ppbv})$ respectively. Thus, the concentration of NO was found to be declined considerably from pre-lockdown days to triple-lockdown days, and the decrease was $61 \%$. The 
244 domination of $\mathrm{O}_{3}$ titration in the presence of high concentration of $\mathrm{NO}$ is the primary reason for

245 the observed low concentration of $\mathrm{O}_{3}$ during pre-lockdown days.

246 In pre-lockdown days, $\mathrm{NO}_{2}$ concentration was found to increase in daytime due to 247 enhanced emissions from vehicles and industries. The diurnal average concentrations of $\mathrm{NO}_{2}$ 248 observed during pre-lockdown, lockdown and triple-lockdown days were (9.6 $\pm 2.1 \mathrm{ppbv}), \quad(4.9 \pm$ $2491.8 \mathrm{ppbv})$, and $(2.8 \pm 0.88 \mathrm{ppbv})$ respectively. Hence, the concentration of $\mathrm{NO}_{2}$ was found to be 250 decreased significantly from pre-lockdown days to triple-lockdown days and the observed 251 decrease was $71 \%$. Conversely, $\mathrm{O}_{3}$ concentrations observed were higher on triple-lockdown and 252 lockdown period than pre-lockdown period, even in the absence of industrial activities and low 253 traffic. Certainly, relatively lesser release of NO during lockdown and triple-lockdown days 254 reduces the $\mathrm{O}_{3}$ scavenging, and hence improved the photochemical production of $\mathrm{O}_{3}$ from its 255 other precursors.

At city-scale, VOC-NOx ratio is the key factor of $\mathrm{O}_{3}$ formation (Pusede and Cohen 257 2012). The urban areas are characterized by a low value of this ratio due to high NOx 258 concentrations (Beekmann and Vautard 2010). In an environment with "VOC-limited" 259 conditions, VOCs concentration is highly sensitive in $\mathrm{O}_{3}$ formation in an environment with high NOx emission. Likewise, the ratio of $\left[\mathrm{NO}_{2}\right] /[\mathrm{NO}]$ that depends on the local concentration of $\mathrm{O}_{3}$, since it is produced by the photodissociation of $\mathrm{NO}_{2}$ and its sink is titration with NO. Thus, $\mathrm{O}_{3}$ increase is due to a lower titration of $\mathrm{O}_{3}$ by $\mathrm{NO}$ due to the strong reduction in local NOx emissions by road transport (Sicard et al. 2020). However, the presence of VOC's and NOx allows the formation of $\mathrm{O}_{3}$ through $\mathrm{NO}_{2}$ photolysis through a complex chemistry (Monks et al. 2015).

The day time average concentrations of $\left[\mathrm{NO}_{2} / \mathrm{NO}\right]$ during pre-lockdown, lockdown and triple-lockdown days were estimated to be $(1.82 \pm 0.8 \mathrm{ppbv}),(1.38 \pm 0.6 \mathrm{ppbv})$, and $(0.86 \pm 0.5$ ppbv) which indicated a reduction of $\left[\mathrm{NO}_{2} / \mathrm{NO}\right]$ by $47 \%$ from pre-lockdown days to triplelockdown days. The ratio between average concentrations of BTEX and NOx were found to be $(1.2 \pm 1.6 \mathrm{ppbv}),(1.65 \pm 1.1 \mathrm{ppbv})$, and $(1.96 \pm 0.82 \mathrm{ppbv})$ during pre-lockdown, lockdown and triplelockdown days respectively; with an increase of $63 \%$ from pre-lockdown days to triplelockdown. During the lockdown period, $\mathrm{O}_{3}$ lapse rate due to the titration of NO might be less than its photochemical production from its precursors, and this may be the primary reason for the enhancement in $\mathrm{O}_{3}$ observed. Further, a strong possibility of VOCs emission from home (e.g. 
275 cleaning fireplaces, painting) and garden activities (e.g. biomass burning) may also have

276 contributed to the $\mathrm{O}_{3}$ increase ( $\mathrm{Su}$ et al. 2003; Murphy et al. 2007; Wolff et al. 2013) in triple-

277 lockdown days. Thus, the reduced concentration in NOx, and any enhancement of biogenic

278 VOC's and their transport may have played a promising role in the enhancement of $\mathrm{O}_{3}$ during

279 triple-lockdown in Kannur town like other cities, which could be confirmed only after further 280 investigations.

281 Diurnal variation of photo-dissociation rate coefficient $\mathrm{j}\left(\mathrm{NO}_{2}\right)$ was computed to estimate

282 the strong dependence of $\mathrm{NO}_{2}$ on the observed enhancement of $\mathrm{O}_{3}$, during lockdown and triple-

283 lockdown days as shown in figure $2(\mathrm{~d})$. The $\mathrm{j}\left(\mathrm{NO}_{2}\right)$ values exhibited the typical pattern of

284 increasing gradually after sunrise, attaining a maximum value during noontime and decreasing

285 during evening-time. The values of $\mathrm{j}\left(\mathrm{NO}_{2}\right)$ gradually increasing in tune with the intensity of solar

286 radiation reaching on the surface. During pre-lockdown days, $\mathrm{O}_{3}$ concentration was increasing in

287 full harmony with the variation of $\mathrm{j}\left(\mathrm{NO}_{2}\right)$. Therefore, a positive correlation is observed between

$288 \mathrm{O}_{3}$ and $\mathrm{j}\left(\mathrm{NO}_{2}\right)$ during day time hours and the photo-dissociation coefficients were low due to the

289 reduced concentration of $\mathrm{NO}_{2}$ in lockdown and triple-lockdown periods. It was further observed

290 that $\mathrm{j}\left(\mathrm{NO}_{2}\right)$ values were decreased in pre-lockdown days and triple-lockdown days by a

291 percentage of $16 \%$. This reveals that the $\mathrm{O}_{3}$ production was the result of photo-dissociation of

$292 \mathrm{NO}_{2}$ in the presence of biogenic VOCs during lockdown and triple-lockdown days.

293

294

295

296

\subsection{Variation of particulate matters $\left(\mathrm{PM}_{10}\right.$ and $\left.\mathrm{PM}_{2.5}\right)$}

The diurnal variations $\mathrm{PM}_{10}$ and $\mathrm{PM}_{2.5}$ during the study period are shown in the figures 3(a) and 3(b). During pre-lockdown days $\mathrm{PM}_{10}$ and $\mathrm{PM}_{2.5}$ showed two peaks; of which one peak in the morning (07:00 -10:00) hours and the other one in the late evening to night time (19:0022:00) hours. Further, moderate levels were observed from night till the early morning hours due to shallow boundary layer (Yadav et al. 2014; Qu et al. 2018). Concentrations of particulate matters showed a morning peak followed by a decline in the afternoon on pre-lockdown days. The observed low concentrations of particulate matters during the afternoon hours can be attributed primarily to the dilution of particles linked with broaden boundary layer and also lesser traffic (Stafoggia et al. 2019).

In the lockdown days, the vehicular emissions were considerably reduced, and the observed magnitude of the morning peak was fairly small; whereas in triple-lockdown days the 305 peak was absent due to the roads were deserted. The diurnal average concentration of $\mathrm{PM}_{10}$ 
306 observed on pre-lockdown days, lockdown days and triple-lockdown days were $307\left(127.8 \pm 21 \mu \mathrm{g} / \mathrm{m}^{3}\right),\left(70.96 \pm 12.6 . \mu \mathrm{g} / \mathrm{m}^{3}\right)$, and $\left(50.2 \pm 10.11 \mu \mathrm{g} / \mathrm{m}^{3}\right)$ respectively. The concentration 308 of $\mathrm{PM}_{10}$ was found to decrease significantly from pre-lockdown days to lockdown days (45\%) 309 and lockdown days to triple-lockdown days (29\%). Likewise, the diurnal average concentration 310 of $\mathrm{PM}_{2.5}$ on pre-lockdown days, lockdown days and triple-lockdown days were $\left(69.4 \pm 17 \mu \mathrm{g} / \mathrm{m}^{3}\right)$, $311\left(45.5 \pm 8 . \mu \mathrm{g} / \mathrm{m}^{3}\right)$, and $\left(32.5 \pm 7.5 \mu \mathrm{g} / \mathrm{m}^{3}\right)$ respectively. The concentration of $\mathrm{PM}_{2.5}$ was found to be 312 decrease extensively from pre-lockdown days to lockdown days (34\%) and lockdown days to 313 triple-lockdown days (29\%).

314 Linear negative correlations are obtained between $\mathrm{PM}_{10}$ and solar radiation (figure 3(c)) 315 and surface $\mathrm{O}_{3}$ (figure 3(d)). The higher concentration of particulate matters on pre-lockdown 316 days can reduce the photolysis rate $\mathrm{j}\left(\mathrm{NO}_{2}\right)$ in the lower troposphere and it can decrease 317 photochemical production of $\mathrm{O}_{3}$ on these days. During pre-lockdown days, the observed low 318 concentration of $\mathrm{O}_{3}$ indicates the different impacts of particulate matters on photolysis 319 frequencies. A strong negative correlation coefficient (-0.91) between $\mathrm{PM}_{10}$ and solar radiation 320 reveals the active daytime photochemistry over Kannur town.

321 Diurnal variation of solar radiation, air temperature, and relative humidity observed over 322 Kannur during the study period is shown in the figures 4(a), 4(b), and 4(c) respectively. Intensity 323 of solar radiation and temperature were increase by $7 \%$ and $4 \%$ from pre-lockdown days to 324 triple-lockdown days and relative humidity decreased by $8 \%$. The increase in solar flux is attributed to the decline in the concentration of particulate matters (Li et al. 2011) in lockdown 326 and triple-lockdown days, and this enhanced atmospheric temperature and declined relative 327 humidity at this site.

\subsection{Diurnal variation of CO, BTEX, $\mathrm{SO}_{2}$ and $\mathrm{NH}_{3}$}

Diurnal variation of $\mathrm{CO}, \mathrm{BTEX}, \mathrm{SO}_{2}$ and $\mathrm{NH}_{3}$ observed during the observational period are shown in the figures 5(a), 5(b), 5(c) and 5(d) respectively. In pre-lockdown days, the diurnal variation of $\mathrm{CO}, \mathrm{BTEX}$ and $\mathrm{SO}_{2}$ shows two distinct peaks; one peak during morning (08:0011:00) hrs and other at late evening. The small duration of the morning peak was due to the expansion of boundary layer height whereas the large evening peak due to the shallow boundary layer. These peaks were associated with high traffic during the morning and evening hours. During lockdown days, a small peak observed in the morning was due to the presence of few vehicles; while the peak was absent in triple-lockdown days due to the roads were deserted. 
The maximum concentration of $\mathrm{CO}$ observed in day time on pre-lockdown days, 338 lockdown days, and triple-lockdown days were (642 $\pm 115 \mathrm{ppbv}),(368 \pm 79 \mathrm{ppbv})$, and 339 (210 $\pm 70 \mathrm{ppbv})$ respectively. The concentration of CO was found to decrease significantly from 340 pre-lockdown days to lockdown days, and lockdown days to triple-lockdown days. The 341 maximum concentration of BTEX observed in day time on pre-lockdown days, lockdown days 342 and triple-lockdown days were $(9.5 \pm 1.4 \mathrm{ppbv}),(6.7 \pm 1.1 \mathrm{ppbv})$, and $(3.7 \pm 0.8 \mathrm{ppbv})$ respectively.

343 The concentration of BTEX was found to be decreased from pre-lockdown days to lockdown 344 days, and lockdown days to triple-lockdown days due to absence of vehicular and industrial 345 emissions.

The diurnal variation of $\mathrm{SO}_{2}$ was most pronounced during traffic hours over Kannur town. The maximum concentration of $\mathrm{SO}_{2}$ observed in day time on pre-lockdown days, lockdown days, and triple-lockdown days were (2.86 $\pm 0.72 \mathrm{ppbv}),(1.82 \pm 0.45 \mathrm{ppbv})$, and $(1.08 \pm 0.32 \mathrm{ppbv})$ respectively. Thus the concentration of $\mathrm{SO}_{2}$ was found to be decrease considerably from pre-lockdown days to lockdown days, and lockdown days to triple-lockdown days. During pre-lockdown period, the daily averaged $\mathrm{NH}_{3}$ concentrations varied from 5.1 to 5.8ppbv. Daily $\mathrm{NH}_{3}$ exhibited a temporal variation with higher concentrations on the noon time hours; due to higher air temperatures and lower wind speeds. High air temperatures will favor $\mathrm{NH}_{3}$ volatilization, and the low wind speeds support the accumulation of air pollutants (Wang et al. 2015; Zhao et al. 2016). The maximum concentration of $\mathrm{NH}_{3}$ observed in day time on prelockdown days, lockdown days, and triple-lockdown days were (5.84 $\pm 0.52 \mathrm{ppbv})$, $(5.32 \pm 0.41 \mathrm{ppbv})$, and $(4.91 \pm 0.32 \mathrm{ppbv})$ respectively. Like other trace pollutants, the concentration of $\mathrm{NH}_{3}$ was also found to be decreased from pre-lockdown period to triplelockdown days due to complete shutdown of traffic and industrial activities in Kannur district.

\subsection{Air quality index during the study period}

The overall air quality index (AQI) of a day is the maximum air quality index of the constituent pollutant, and the corresponding pollutant is the dominating pollutant. Figure 6 represents the variation of air quality index during the study period over Kannur town. The highest index of $235 \pm 32$ which refers to poor air quality was observed in pre-lockdown period from 1 to 5 in March, during which the vehicular traffic was quite normal. From the figure, it is observed that the AQI was declining from $25^{\text {th }}$ March coincides with the beginning of lockdown. 
$368118 \pm 20$ in the following days. Since the triple-lockdown in Kannur was implemented on $20^{\text {th }}$

369 April, the value of AQI further come down and reached its lowest level at $48 \pm 10$ due to the ban 370 of complete vehicles on the road. As a result, air pollution was highly reduced by which the air

371 became unpolluted at this site. Thus, the enhanced air quality resulted from the triple-lockdown

372 may prevent the virus spread in Kannur district.

373 Conclusion

374 The present study revealed a drastic reduction in air pollution over Kannur a town in 375 north of Kerala state India, which was identified as one of the "first hotspots" of COVID 19 by 376 the Government of India. Subsequently, a triple-lockdown was implemented from 20 April for 377 further twenty days that restricted the movement of people. A considerable reduction in 378 atmospheric air pollutants over this region was observed during the lockdown and triple379 lockdown periods at this site. The highlights of the observation are the following:

$>$ Surface $\mathrm{O}_{3}$ concentration was increased to $22 \%$ in triple-lockdown period while NO and $\mathrm{NO}_{2}$ concentrations were decreased to $61 \%$ and $71 \%$ from pre-lockdown days to triplelockdown days. The primary reason for the increase in $\mathrm{O}_{3}$ is due to the reduction in titration of $\mathrm{O}_{3}$ with NO. The sensitivity of VOC's (both biogenic and industrial) could be confirmed by measuring them on a long-term basis. The calculated diurnal profile of $\mathrm{j}\left(\mathrm{NO}_{2}\right)$ values showed a maximum reduction in triple-lockdown period due to the decrease in $\mathrm{NO}_{2}$.

$>$ The concentration of CO, VOC's (BTEX), $\mathrm{SO}_{2}$ and $\mathrm{NH}_{3}$ were declined to $67 \%, 61 \%$, $62 \%$ and $16 \%$ respectively from pre-lockdown days to triple-lockdown days.

> The concentration of $\mathrm{PM}_{10}$ and $\mathrm{PM}_{2.5}$ were decreased to $61 \%$ and $53 \%$ respectively. Further, the increase in solar flux observed was mainly due to the absence of scattering and absorption of aerosols present in the atmosphere due to lockdown.

$>$ The air quality index (AQI) analysis revealed that the air quality in Kannur was quite improved during lockdown period.

The dramatic decline in air pollution during this lockdown has significant immediate consequences. Exposure to high levels of particulate matters and trace gases has substantial detrimental effects on human health. Many researchers have hypothesized that the drop in air pollution levels may currently be saving a significant amount of lives, not only by reducing 
398 individuals' susceptibility to COVID-19, but also by preventing world's seven million annual 399 deaths due to air pollution exposure.

400 Yao et al. (2020) analysed the death rate due to COVID-19 and spatial correlation of $401 \mathrm{PM}_{10}$ and $\mathrm{PM}_{2.5}$ in China, and they revealed that higher concentration of $\mathrm{PM}_{10}$ and $\mathrm{PM}_{2.5}$ had a 402 positive correlation with deaths caused by COVID-19. Wu et al. (2020) suggested that, long403 term exposure to fine particulate matter $\left(\mathrm{PM}_{2.5}\right)$ induced a risk of COVID-19. Further, they found 404 that an increase of $1 \mu \mathrm{g} / \mathrm{m}^{3}$ in $\mathrm{PM}_{2.5}$ enhanced $8 \%$ morbidity due to COVID-19 in the United 405 States. Fattorini and Regoli (2020) suggested that, chronic exposure of particulate matters $\left(\mathrm{PM}_{10}\right.$ 406 and $\mathrm{PM}_{2.5}$ ) could aggravate the susceptibility of COVID-19 infection. A positive correlation 407 exhibited between concentrations of $\mathrm{PM}_{10}, \mathrm{PM}_{2.5}, \mathrm{SO}_{2}, \mathrm{NO}_{2}, \mathrm{CO}$ and COVID-19 outbreak in 408 California (Bashir et.al 2020). It is reported, that air pollution has a positive association with 409 COVID-19 confirmed cases in China (Zhu et al. 2020). Thus, this improvement in air quality 410 during lock down might have played a vital role in bringing reduced susceptibility of virus 411 getting infected into the lungs. The enhancement in the air quality induced by triple-lockdown 412 might be one of the prime reasons by which Kerala could flatten the transmission curve for the 413 first time in India. This association of air quality and spread of COVID if confirmed by future 414 studies suggest that air quality should also be considered as part of an integrated approach 415 towards human health protection and prevention of the epidemic spreads.

\section{Acknowledgement}

417 This work is carried out with the support of ISRO- GBP (AT-CTM) programme and Kerala State 418 Council for Science Technology and Environment (KSCSTE). The authors wish to thank Dr. Shyam Lal Programme Director of (AT-CTM) for his support and inspiration. Resmi expresses her gratitude to Dr. R. Venkatachalam (Principal) and Dr.D.Manivannan (HOD of Physics) of Erode Arts and Science College Tamil Nadu for providing the necessary facilities. Dr. KT Valsaraj would like to thank the Charles and Hilda Roddey Professorship at LSU for supporting this work. Authors gratefully acknowledge the effort made by Dr. G Beig, Academic Editor of Peerj, and the other three anonymous reviewers for the critical reviewing of the manuscript and making valuable suggestions for the improvement of the manuscript in the present form.

\section{Reference}


Al-Qahtani A. 2020. Severe Acute Respiratory Syndrome Coronavirus 2 (SARS-CoV-2): Emergence history basic and clinical aspects. Saudi Journal of Biological Sciences doi.org/101016/jsjbs202004033.

Atkinson R. 2000. Atmospheric chemistry of VOCs and NOx. Atmospheric Environment 34: 2063-2101. doi.org/10.1016/S1352-2310(99)00460-4

Bao R, Zhang A.2020. Does lockdown reduce air pollution? Evidence from 44 cities in northern China. Science of the Total Environment 731: 139052

Bashir, MF, Jiang BMA, Bilal, Komal B, Bashir MA, Farooq TH, Iqbal N, Bashir M. 2020. Correlation between environmental pollution indicators and COVID-19 pandemic: A brief study in Californian context. Environmental Research 187 (2020) 109652. doi.org/10.1016/j.envres.2020.109652

Bauwens M, Compernolle S, Stavrakou T, Müller J-F, van Gent J, Eskes H, Levelt PF, van der A R, Veefkind JP, Vlietinck J, Yu H, Zehner C. 2020. Impact of coronavirus outbreak on $\mathrm{NO}_{2}$ pollution assessed using TROPOMI and OMI observations. Geophysical Research Letters.

doi: 101029/2020GL087978.

Beekmann M, Vautard R. 2010. A modelling study of photochemical regimes over Europe: robustness and variability. Atmospheric Chemistry and Physics 10: 10067-10084

Beig G, Ghude SD, Deshpande A. 2010. Scientific evaluation of air quality standards and defining air quality Index for India Indian Institute of Tropical Meteorology, Ministry of Earth Science Government of India.

Chen B, Kan H. 2008. Air pollution and population health: a global challenge. Environ Health and Preventive Medicine 13:94-101. doi: 10.1007/s12199-007-0018-5.

Cheng Y, Ho KF, Lee SC, Law SW. 2006. Seasonal and diurnal variations of $\mathrm{PM}_{10} \mathrm{PM}_{25}$ and $\mathrm{PM}_{10}$ in the roadside environment of Hong Kong China. Particuology 4: 312-315

CPCB. 2014. National Air Quality Index Report. Central Pollution Control Board, New Delhi, India.

Dantas G, Siciliano B, França BB, da Silva CM, Arbilla G. 2020. The impact of COVID-19 partial lockdown on the air quality of the city of Rio de Janeiro Brazil. Science of the Total Environment 729: 139085 DOI: doiorg/101016/jscitotenv2020139085.

Ding M, Tian B, Ashley M, Zhu Z, Wang L, Yang S, Li C, Xiao C, Qin D. 2020. Yearround record of near-surface ozone and " $\mathrm{O}_{3}$ enhancement events" (OEEs) at Dome A, East Antarctica. Atmospheric Chemistry and Physics doi.org/10.5194/acp-2019-1042.

Duncan BN, Logan JA. 2008. Model analysis of the factors regulating the trends and variability of carbon monoxide between 1988 and 1997. Atmospheric Chemistry and Physics 8: 7389-7403. doi.org/10.5194/acp-8-7389-2008

Dutheil F, Baker SJ, Navel V. 2020. COVID-19 as a factor influencing air pollution?. Environmental Pollution doi.org/101016/jenvpo 12020114466.

Fattorini D, Regoli F. 2020. Role of the atmospheric pollution in the Covid-19 outbreak risk in Italy. medRxiv 10.1101/2020.04.23.20076455

Franco JF, Pacheco J. 2015. Characterization and source identification of VOC species in Bogota Colombia. Atmosfera 28: 1-11.

Fuentes JD, Lerdau M, Atkinson R, Baidocchi D, Bottenheim JW, Ciccioli P, Lamb B, Geron C, Go L, Guenther A, Sharkey TG, Stockwell W. 2000. Biogenic hydrocarbons in the atmospheric boundary layer: a review. Bulletin of American Meteorological Society 81:1537-1575. 
Gautam S, Hens L. 2020. SARS-CoV-2 pandemic in India: what might we expect?. Environment, Development and Sustainability 22: 3867-3869.

Gautam S. 2020. The Influence of COVID-19 on air quality in India:A Boon or Inutile. Bulletin of Environmental Contamination and Toxicology doi.org/101007/s00128-020-02877-y.

Guo H, Kota SH, Sahu SK, Hu J, Ying Q, Gao A. 2017. Source apportionment of PM 2.5 in North India using source-oriented air quality models. Environmental Pollution 231: 426436.

Guo H, Kota SH, Sahu SK, Zhang H. 2019. Contributions of local and regional sources to $\mathrm{PM}_{2.5}$ and its health effects in north India. Atmospheric Environment 214: 116867.

Kanniah KD, Kamarul Zaman NAF, Kaskaoutis GD, Latif MT. 2020. COVID-19's impact on the atmospheric environment in the Southeast Asia region. Science of the Total Environment 736:139658

Kinoshita H, Türkan H, Vucinic S, Naqvi S, Bedair R, Rezaee R, Tsatsakis A. 2020. Carbon monoxide poisoning. Toxicology Reports 7: 169-173 doi.org/10.1016/j.toxrep.2020.01.005.

Lawrence MG, Lelieveld J. 2010. Atmospheric pollutant outflow from southern Asia: a review. Atmospheric Chemistry and Physics 10: 11017-11096..

Li J, Wang Z, Wang X, Yamaji K, Takigawa M, Kanaya Y, Pochanart P, Liu Y, Irie H, Hu B. 2011. Impacts of aerosols on summertime tropospheric photolysis frequencies and photochemistry over Central Eastern China. Atmospheric Environment 45: 1817-1829

Liu Z, Hu B, Wang L, Wu F, Gao W, Wang Y. 2015. Seasonal and diurnal variation in particulate matter $\left(\mathrm{PM}_{10}\right.$ and $\left.\mathrm{PM}_{25}\right)$ at an urban site of Beijing: analyses from a 9-year study. Environmental Science and Pollution Research 22: 627-42doi: 101007/s11356014-3347-0.

Liu Y, Shao M, Lu S, Chang CC, Wang JL, Chen G. 2008. Volatile Organic Compound (VOC) measurements in the Pearl River Delta (PRD) region, China. Atmospheric Chemistry and Physics 8:1531-1545 doi.org/10.5194/acp-8-1531-2008.

Lu H, Stratton CW, Tang Y-W. 2020. Outbreak of pneumonia of unknown etiology in Wuhan China: The mystery and the miracle. Journal of Medical Virology 92: 401-402.

Lu X, Hong J, Zhang L, Cooper OR, Schultz MG, Xu X, Wang T, Gao M, Zhao Y, Zhang Y. 2018 Severe surface Ozone Pollution in China: A global perspective. Environmental Science and Technology Letters. 5: 487-494.

Mahato S, Pal S, Ghosh KG. 2020. Effect of lockdown amid COVID-19 pandemic on air quality of the megacity Delhi, India. Science of the Total Environment 730: 139086. doi.org/10.1016/j.scitotenv.2020.139086.

Maji S, Beig G, Yadav R. 2020. Winter VOCs and OVOCs Measured With PTR-MS at an Urban Site of India: Role of Emissions, Meteorology and Photochemical Sources. Environmental Pollution 258:113651.doi: 10.1016/j.envpol.2019.

Mallik C, Lal S. 2014. Seasonal characteristics of $\mathrm{SO}_{2}, \mathrm{NO}_{2}$, and $\mathrm{CO}$ emissions in and around the Indo-Gangetic plain. Environmental Monitoring and Assessment 186: 1295-1310.

Menchaca-Torre HL, Mercado-Hernandez R, Mendoza-Domínguez A. 2015. Diurnal and seasonal variation of volatile organic compounds in the atmosphere of Monterrey, Mexico. Atmospheric Pollution Research 6:1073-1081.

Monks PS, Archibald AT, Colette A, Cooper O, Coyle M, Derwent R, Fowler D, Granier C, Law KS, Mills GE, Stevenson DS, Tarasova O, Thouret V, Schneidemesser E V, Sommariva R, Wild O, Williams ML. 2015. Tropospheric ozone and its precursors 
from the urban to the global scale from air quality to short-lived climate forcer. Atmospheric Chemistry and Physics 15: 8889-8973.

Montero-Montoya R, Lopez-Vargas R, Arellano-Aguilar O. 2018. Volatile organic compounds in air: sources distribution exposure and associated illnesses in children. Annals of Global Health 84: 225-238.

Muhammad S, Long X, Salman M. 2020. COVID-19 pandemic and environmental pollution: A blessing in disguise? Science of the Total Environment 138820. doi.org/10.1016/j.scitotenv.2020.138820.

Murphy JG, Day DA, Cleary PA, Wooldridge PJ, Millet DB, Goldstein A H, Cohen RC. 2007. The weekend effect within and downwind of Sacramento-part 1: observations of ozone nitrogen oxides and VOC reactivity. Atmospheric Chemistry and Physics 7: 53275339.

Nakada LYK, Urban RC. 2020. COVID-19 pandemic: Impacts on the air quality during the partial lockdown in São Paulo state Brazil. Science of the Total Environment. 730139089 doi.org/101016/jscitotenv2020139087.

Nishanth T, Praseed KM, Satheesh Kumar MK, Valsaraj KT. 2014. Influence of ozone precursors and $\mathrm{PM}_{10}$ on the variation of surface $\mathrm{O}_{3}$ over Kannur India. Atmospheric Research 138: 112-124.

Pandolfi M, Amato F, Reche C, Alastuey A, Otjes RP, Blom MJ, Querol X. 2012. Summer ammonia measurements in a densely populated Mediterranean city. Atmospheric Chemistry and Physics 12: 7557-7575.

Phan NT, Kim KH, Shon ZH, Jeon EC, Jung K, Kim NJ. 2013. Analysis of ammonia variation in the urban atmosphere. Atmospheric Environment 65: 177-185.

Pusede SE, Cohen RC. 2012. On the observed response of ozone to NOx and VOC reactivity reductions in San Joaquin Valley California 1995-present. Atmospheric Chemistry and Physics. 12: 8323-8339.

Qu Y, Wang T, Cai Y, Wang S, Chen P, Li S, Li M, Yuan C, Wang J, Xu S. 2018. Influence of atmospheric particulate matter on ozone in Nanjing China: Observational study and mechanistic analysis. Advances in Atmospheric Science 35(11) 1381-1395.

Qu YW, Han Y, Wu YH, Gao P, Wang TJ. 2017. Study of PBLH and its correlation with particulate matter from one-year observation over Nanjing Southeast China. Remote Sensing 9: 668 doi.org/103390/rs9070668.

Resmi CT, Nishanth T, Satheesh Kumar MK, Balachandramohan M, Valsaraj KT. 2020. Long-Term Variations of Air Quality Influenced by Surface Ozone in a Coastal Site in India: Association with Synoptic Meteorological Conditions with Model Simulations. Atmosphere. 11: 193. doi:10.3390/atmos11020193.

Sahu SK, Kota SH. 2017.Significance of $\mathrm{PM}_{2.5}$ air quality at the Indian capital. Aerosol and air quality research 17: 588-597.

Sharma S, Zhang M, Gao AJ, Zhang H, Kota SH. 2020. Effect of restricted emissions during COVID-19 on air quality in India. doi.org/10.1016/j.scitotenv.2020.138878.

Shi X, Brasseur GP. 2020. The response in air quality to the reduction of Chinese economic activities during the COVID-19 Outbreak. Geophysical Research Letters doi.org/101029/2020GL088070.

Sicard P, Marco AD, Agathokleous E, Feng Z, Xu X, Paoletti E, Rodriguez JJD, Calatayud V. 2020. Amplified ozone pollution in cities during the COVID-19 lockdown. Science of the Total Environment 735: 139542, doi.org/10.1016/j.scitotenv.2020.139542. 
567

Srivastava A, Sengupta B, Dutta SA. 2005. Source apportionment of ambient VOCs in Delhi city. Science of the Total Environment 343: 207-220.

Stafoggia M, Bellander T, Bucci S, Davoli M, de Hoogh K, de' Donato F, Gariazzo C, Lyapustin A, Michelozzi P, Renzi M, Scortichini M, Shtein A, Viegi G, Kloog I, Schwartz J. 2019. Estimation of daily $\mathrm{PM}_{10}$ and $\mathrm{PM}_{25}$ concentrations in Italy 2013-2015 using a spatiotemporal land-use random-forest model. Environment International 124: 170-179.

Su FC, Mukherjee B, Batterman S. 2003. Determinants of personal indoor and outdoor VOC concentrations: an analysis of the RIOPA data. Environmental Research 126: 192-203.

Tobías A, Carnerero C, Reche C, Massagué J, Via M, Minguillón MC, Alastuey A, Querol X. 2020. Changes in air quality during the lockdown in Barcelona (Spain) one month into the SARS-CoV-2 epidemic. Science of the Total Environment 726: 138540. doi.org/10.1016/j.scitotenv.2020.138540.

Wang P, Chen K, Zhu S, Wang P, Zhang H. 2020. Severe air pollution events not avoided by reduced anthropogenic activities during COVID-19 outbreak. Resources, Conservation \& Recycling 158: 104814. doi.org/10.1016/j.resconrec.2020.104814

Wang Q, Su M. 2020. A preliminary assessment of the impact of COVID -19 on environmentA case study of China. Science of the Total Environment doi.org/10.1016/j.scitotenv.2020.138915.

Wang S, Nan J, Shi C, Fu Q, Gao S, Wang D, Cui H, Saiz-Lopez A, Zhou B. 2015. Atmospheric ammonia and its impacts on regional air quality over the megacity of Shanghai China. Nature Scientific Reports 5: 15842.

Wolff GT, Kahlbaum DF, Heuss JM. 2013. The vanishing ozone weekday/weekend effect. Journal of Air Waste Management Association 63: 292-299.

Wu X, Nethery RC, Sabath BM, Braun D, Dominici F. 2020. Exposure to air pollution and COVID-19 mortality in the United States. medRxiv. doi.org/10.1101/2020.04.05.20054502

Yadav R, Sahu LK, Beig G, Tripathi N, Maji S, Jaaffrey SNA. 2019a. The role of local meteorology on ambient particulate and gaseous species at an urban site of western India. Urban climate 28: 100449. doi.org/10.1016/j.uclim.2019.01.003.

Yadav R, Sahu LK, Beig G, Jaaffre SNA. 2016. Role of long-range transport and local meteorology in seasonal variation of surface ozone and its precursors at an urban site in India. Atmospheric Research 176:96-107.

Yadav R, Sahu LK, Jaaffrey SNA, Beig G. 2014. Temporal variation of particulate Matter (PM) and potential sources at an urban site of Udaipur in western India. Aerosol and Air Quality Research 14: 1613-1629.

Yadav R, Sahu LK, Tripathi N, Pal D, Beig G, Jaffrey SNA. 2019b. Investigation of emission characteristics of NMVOCs over urban site of Western India. Environmental Pollution 2252: 245-255. doi: 10.1016/j.envpol.2019.05.089.

Yao Y, Pan J, Wang W, Liu Z, Kan H, Meng X, Wang W. 2020. Spatial correlation of particulate matter pollution and death rate of COVID-19. medRxiv doi.org/10.1101/2020.04.07.20052142

Zhang L, Lee CS, Zhang R, Chen L. 2017. Spatial and temporal evaluation of long term trend (2005-2014) of OMI retrieved $\mathrm{NO}_{2}$ and $\mathrm{SO}_{2}$ concentrations in Henan Province China. Atmospheric Environment 154: 151-166. 
612 Zhao M, Wang S, Tan J, Hua Y, Wu D, Hao J. 2016. Variation of urban atmospheric 613 ammonia pollution and its relation with $\mathrm{PM}_{25}$ chemical property in winter of Beijing China. Aerosol and Air Quality Research 16: 1378-1389.

Zhu Y, Xie J, Huang F, Cao L. 2020. Association between short-term exposure to air pollution and COVID-19 infection: Evidence from China. Science of the Total Environment 727: 138704 doi.org/101016/jscitotenv2020138704.

618 
Figure 1

(A) Kannur in South India (B) aerial view of Kannur town and the observational site.
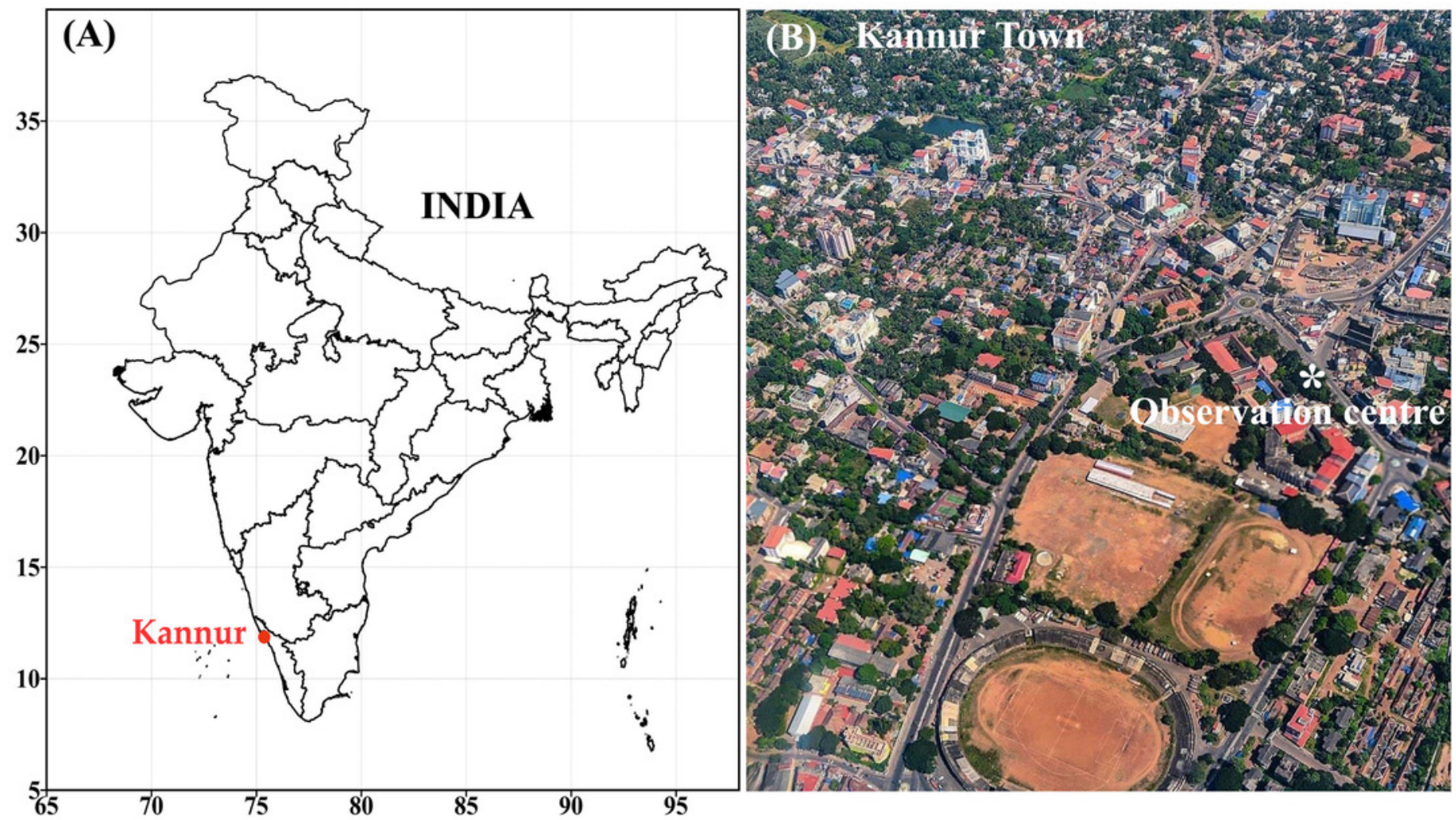
Figure 2

Diurnal variation of (a) surface ozone (b) $\mathrm{NO},(\mathrm{c}) \mathrm{NO}_{2},(\mathrm{~d}) \mathrm{j}\left(\mathrm{NO}_{2}\right)$ between 1 March and 17 May, 2020.
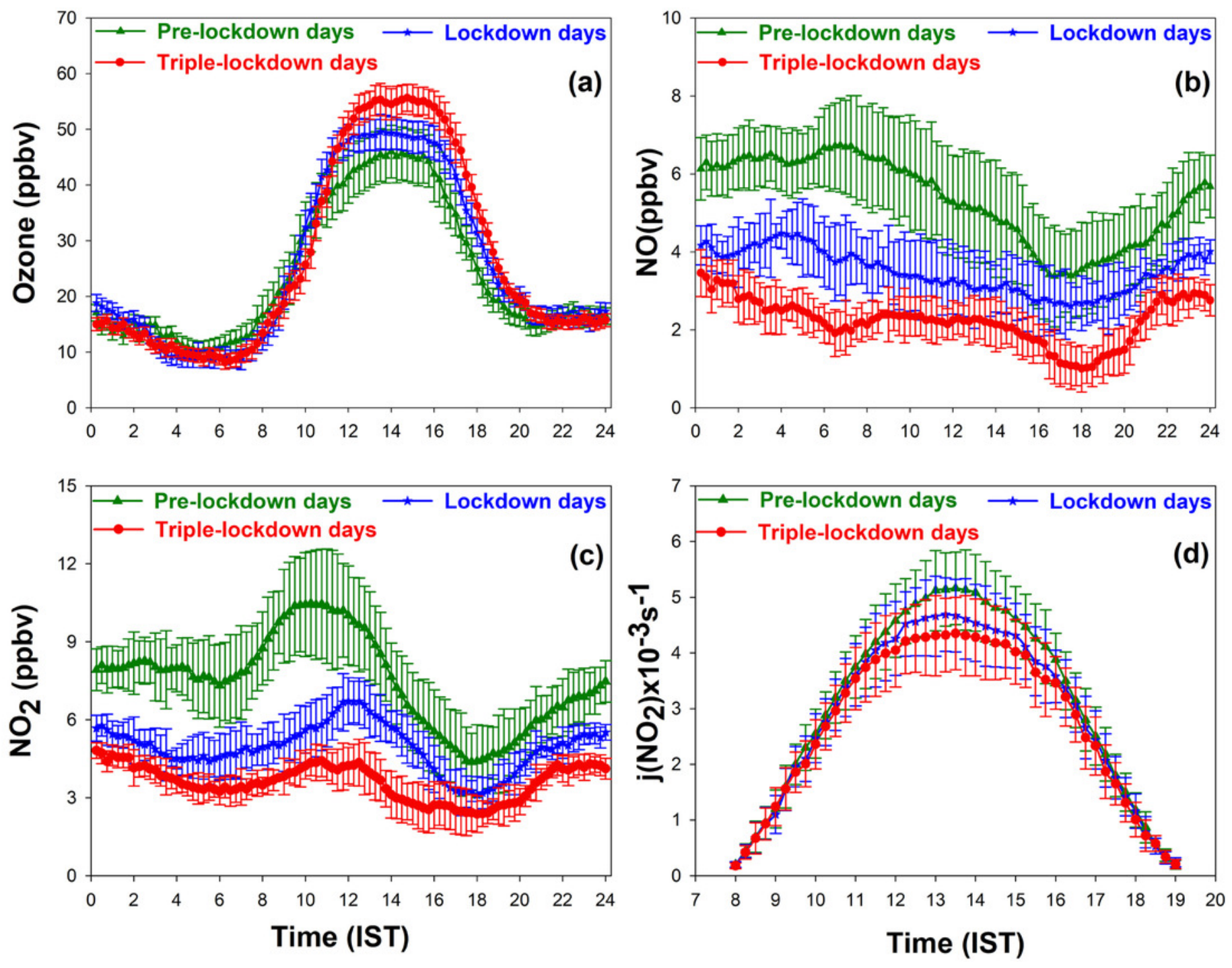
Figure 3

Diurnal variation of (a) $\mathrm{PM}_{10}$ (b) $\mathrm{PM}_{2.5}$ and the scatter plot showing the linear correlation between (c) $\mathrm{PM}_{10}$ and solar radiation (d) $\mathrm{PM}_{10}$ and surface $\mathrm{O}_{3}$.
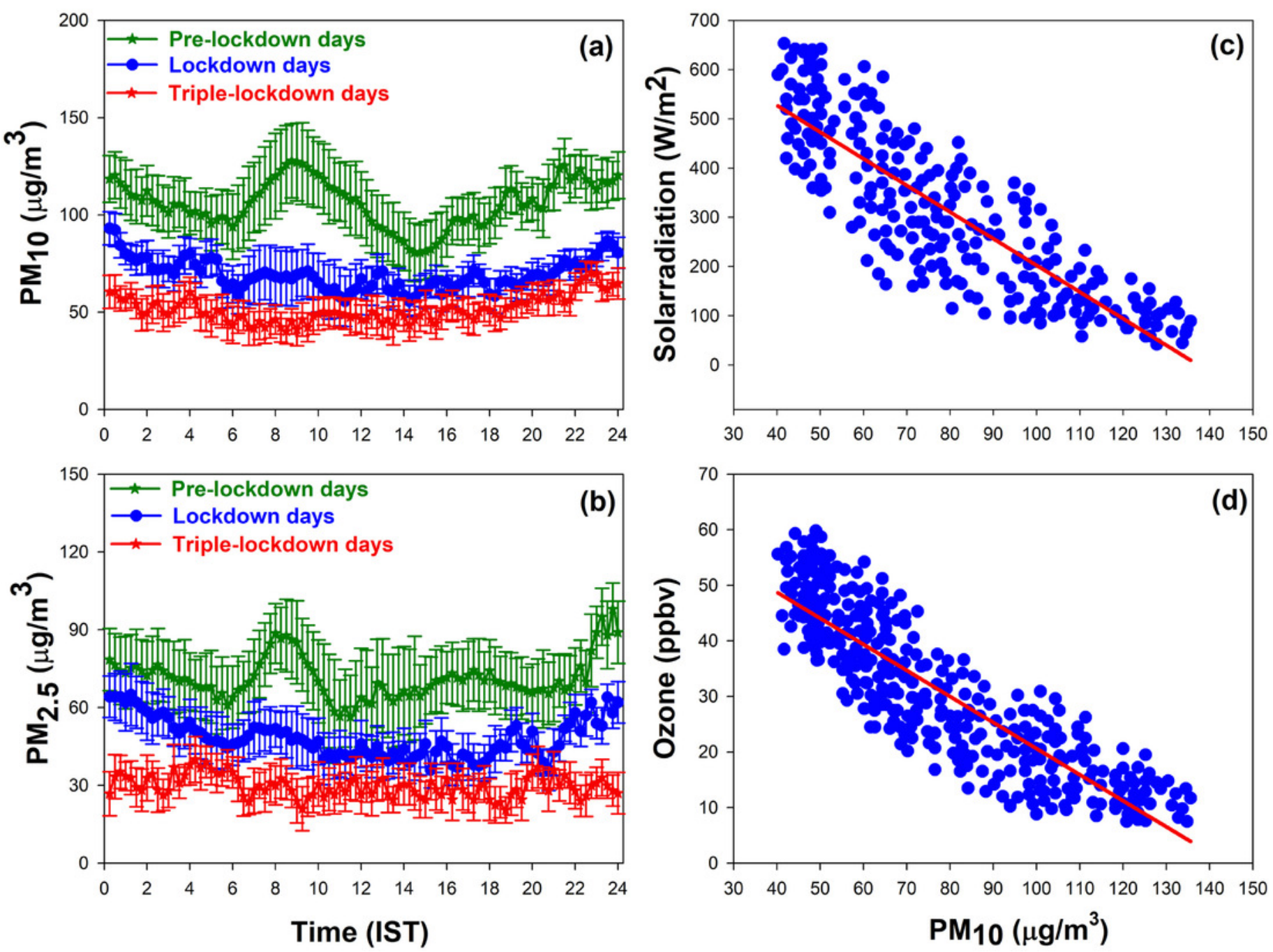
Figure 4

Diurnal variation of (a) solar radiation (b) air temperature (c) relative humidity. 

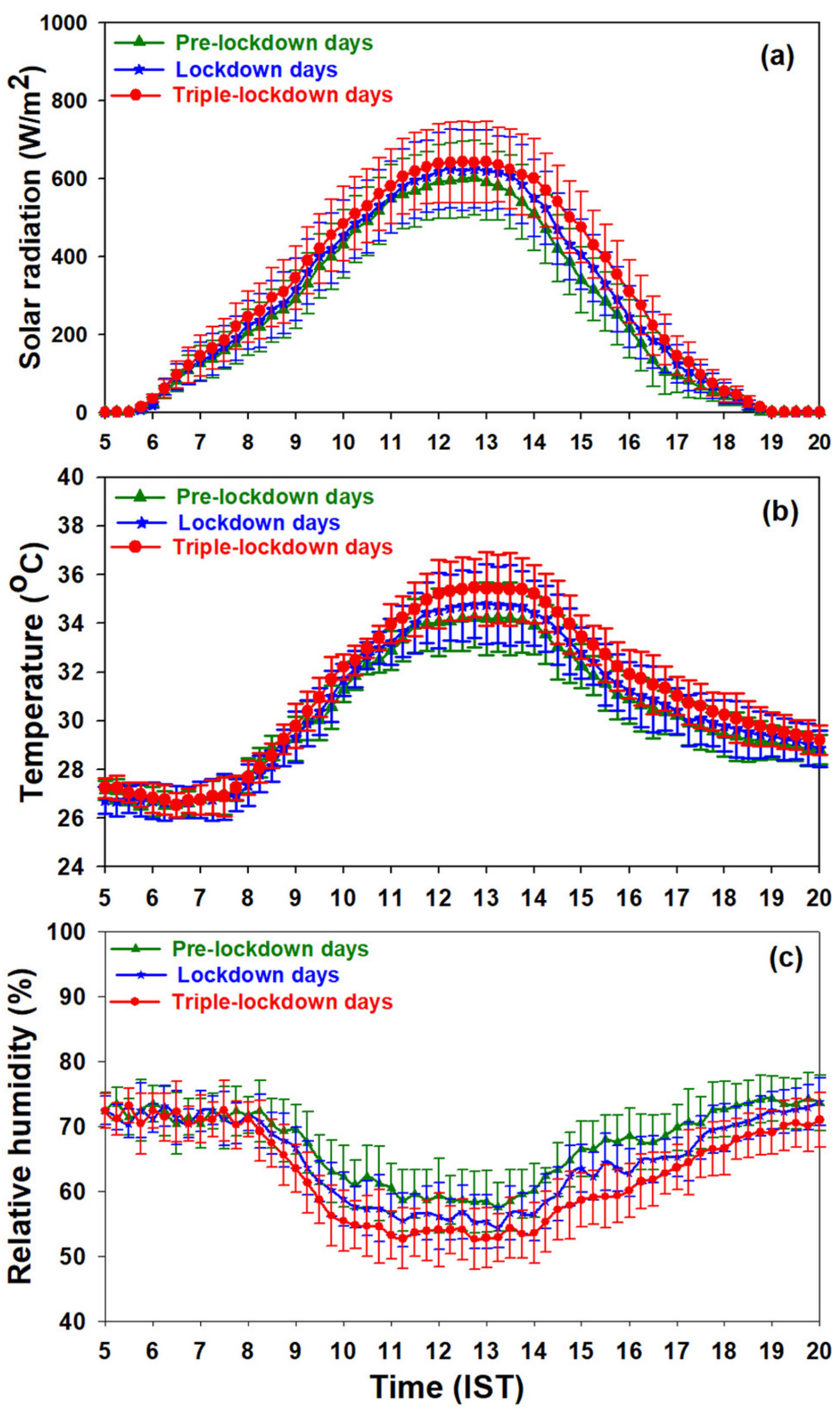
Figure 5

Diurnal variation of (a) $\mathrm{CO}$, (b) BTEX (c) $\mathrm{SO}_{2}$ (d) $\mathrm{NH}_{3}$ observed during the period
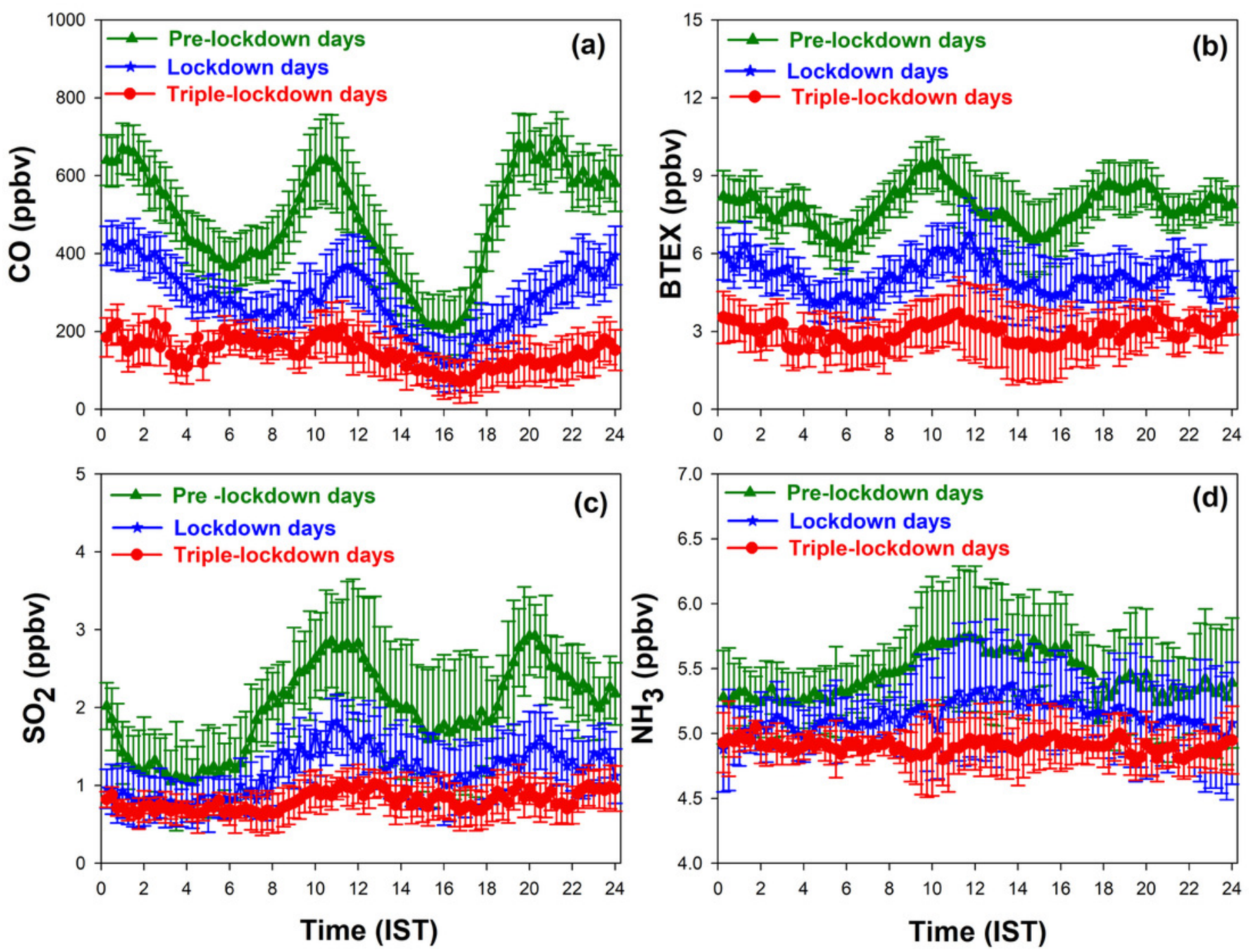
Figure 6

Air quality index for pre-lockdown, lockdown and triple lockdown period

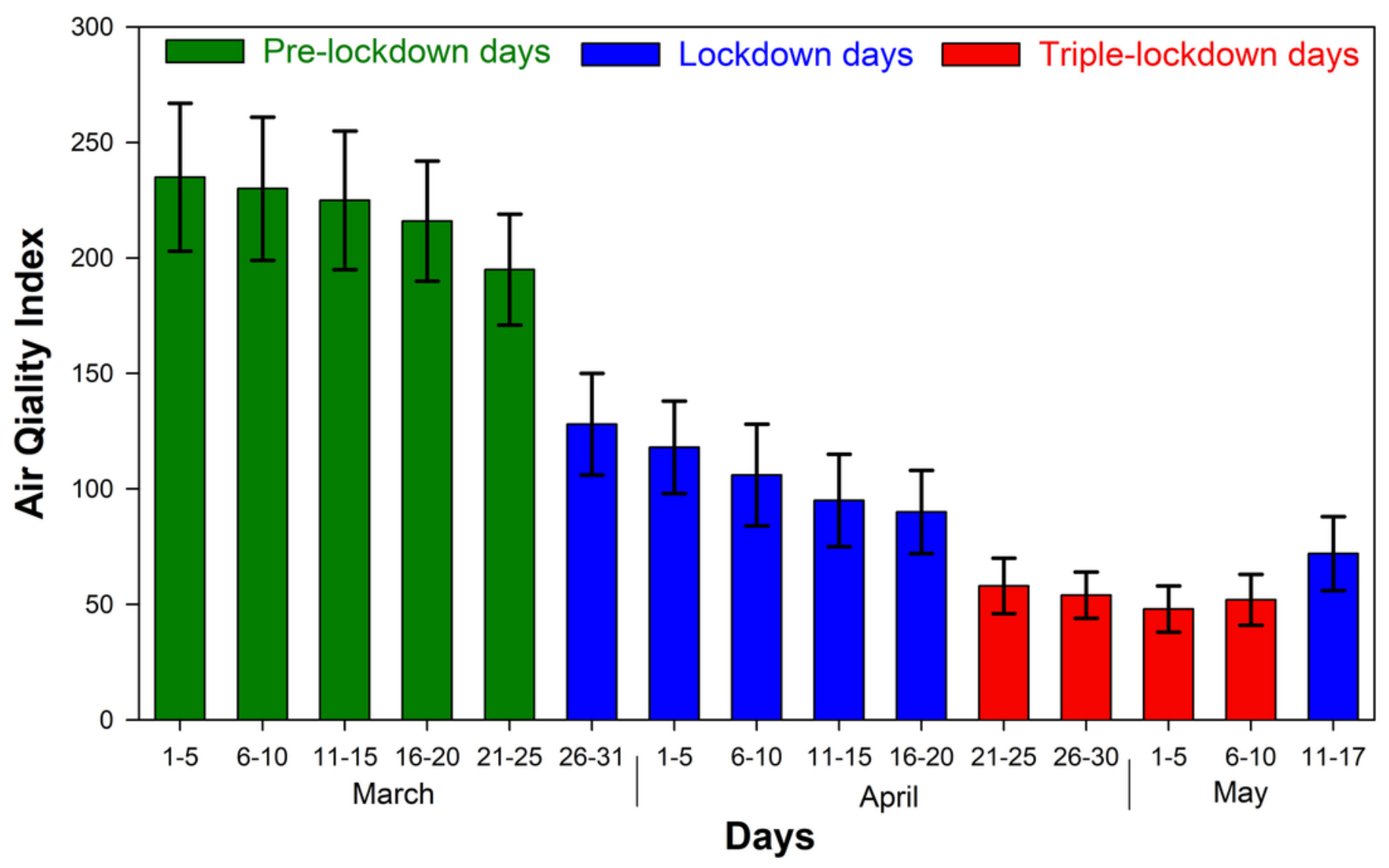




\section{Table $\mathbf{1}$ (on next page)}

Breakpoint of different pollutants for AQI calculation, by CPCB, 2014 


\section{List of tables:}

2

3

4

5

\begin{tabular}{|l|l|l|l|l|l|l|l|}
\hline $\begin{array}{l}\text { AQI } \\
\text { Category } \\
\text { (Range) }\end{array}$ & $\begin{array}{l}\mathrm{PM}_{10} \\
24-\mathrm{hr}\end{array}$ & $\begin{array}{l}\mathrm{PM}_{2.5} \\
24-\mathrm{hr}\end{array}$ & $\begin{array}{l}\mathrm{NO}_{2} \\
24-\mathrm{hr}\end{array}$ & $\begin{array}{l}\mathrm{SO}_{2} \\
24-\mathrm{hr}\end{array}$ & $\begin{array}{l}\mathrm{NH}_{3} \\
24-\mathrm{hr}\end{array}$ & $\begin{array}{l}\mathrm{O}_{3} \\
8-\mathrm{hr}\end{array}$ & $\begin{array}{l}\mathrm{CO} \\
8-\mathrm{hr}\end{array}$ \\
\hline $\begin{array}{l}\text { Good } \\
(0-50)\end{array}$ & $0-50$ & $0-30$ & $0-40$ & $0-40$ & $0-200$ & $0-50$ & $0-1.0$ \\
\hline $\begin{array}{l}\text { Satisfactory } \\
(51-100)\end{array}$ & $51-100$ & $31-60$ & $41-80$ & $41-80$ & $201-400$ & $51-100$ & $1.1-2.0$ \\
\hline $\begin{array}{l}\text { Moderate } \\
(101-200)\end{array}$ & $101-250$ & $61-90$ & $81-180$ & $81-380$ & $401-800$ & $101-168$ & $2.1-10$ \\
\hline $\begin{array}{l}\text { Poor } \\
(201-300)\end{array}$ & $251-350$ & $91-120$ & $181-280$ & $381-800$ & $801-1200$ & $169-208$ & $10.1-17$ \\
\hline $\begin{array}{l}\text { Very Poor } \\
(301-400)\end{array}$ & $351-430$ & $121-$ & $281-400$ & $801-1600$ & $1200-1800$ & $209-748$ & $17.1-34$ \\
\hline $\begin{array}{l}\text { Severe } \\
(401-500)\end{array}$ & $430+$ & 250 & $400+$ & $1600+$ & $1800+$ & $748+$ & $34+$ \\
\hline
\end{tabular}

6

7

8 